\title{
Formation of Engineering Capability Matrix of Production Procedure
}

\author{
Elena Egorova, Aidar Akhmadiev \\ Kazan national research technical university A.N. Tupolev - KAI, Kazan, Russia
}

\begin{abstract}
This article is devoted to the issue of formation of engineering capability matrices of production procedure using intelligent system of process development based on decomposition of procedure design to elementary level. Insufficient information at the stage of preproduction significantly increases the risk of adoption of inefficient decision with considerable increase in time consumption for management. Production procedure depends both on numerous factors of production and on those described by typical elements and links (informational, spatial, time related) of process procedure. The engineering capability matrix of production process is developed on the basis of decomposition of production procedure to seven levels of description.
\end{abstract}

Key words : artificial intelligence, production procedure, capability matrix, production process.

\section{INTRODUCTION}

Intelligent system of metal-forming processes was analyzed in $[1,2]$, which made it possible to conclude that the main tasks of processing strategy for technologist were such components of design system as processing machine, accessory, and cutting tool. Correct selection of each component of design system influences the processing quality of piece and competitiveness of production with consideration for subjective and rational selection at each design step. The methods of object-oriented approach to formalized solution to processing strategy are described in $[3,4]$.

While generating matrices of engineering capabilities of production process procedure, each component of decision making is considered as separate system with its properties, input and output parameters aiming at detection of common properties and development of functional models of engineering capabilities during decision making [5, 6]. It is proposed [7] to consider designed product in terms of variations of production processes. With this aim, it was proposed [8] to present information about workpiece by its design properties, which allowed to develop integrally matrices of engineering capabilities of production process procedure in intelligent system of development of production processes on the basis of decomposition of procedure designing to elemental level.

\section{METHODS}

Generally, numerous orders are processed at the place of production, which exerts different effect on load of equipment and, finally, on total cost of production. In order to adopt automated engineering solution at the level of procedure, the possibility to present it in the form of matrices is required, which are described by typical elements and their interlinks (informational, spatial, time related). Thus, it is necessary to select alternative decisions on the basis of consideration of several indices. The structure of engineering procedures is predetermined at the stage of engineering preproduction by ranking in terms of integral indices. For exact determination of equipment-piece properties, for selection of structure of engineering procedures, the methods are developed on the basis of matrix approach. Engineering equipment for process description is systematized by main properties of production process. The same is carried out for a piece. This is required for efficiency and completeness of data for all possible variants of implementation of engineering procedure. Design technology is also analyzed for prediction of final performances. The most labor consuming procedure is prediction of all quantitative properties of engineering procedure for each designed variant. Such quantitative properties include engineering transitions, system of criteria for selection of the most optimum structure of engineering procedures with consideration for total expenses. Engineering procedure is comprised of numerous constituents, each of them performs definite function. Such interdependence of the functions is structured on the basis of hierarchical levels (Fig. 2). In our case, in the development of matrix of procedure engineering capabilities, a structural element is the finalized process executed in a simple cell of organization structure and embedded technology, which is presented as a system of predictions.

\section{RESULTS AND DISCUSSION}

In the frames of existing approach to automated design of mechanical processing, the $i_{\text {-th }}$ procedure of production process (Fig. 1) is generated by the sequence of selection of specification lines from database of automated system in strict order defined by Unified system for technological documentation. While generating matrices of procedure engineering capabilities, let us analyze the lines of the $i$-th production process procedure aiming at decomposition of process and system of further predictions [9]. 


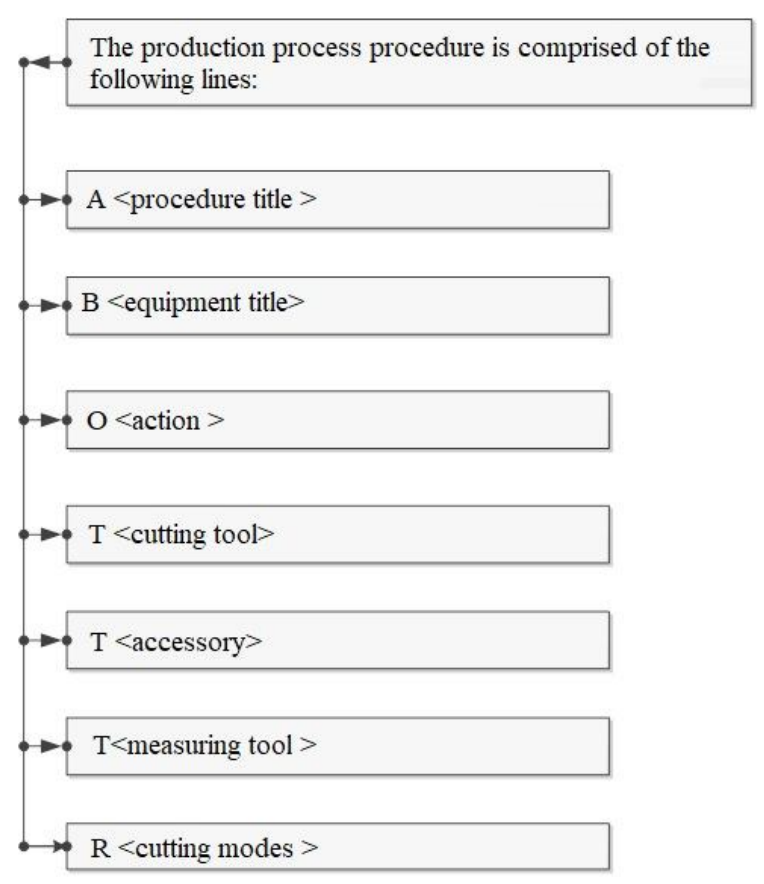

Figure 1: The i-th production process procedure.

Line A <procedure title> is generated by selection from databases of automated system;

Line B <equipment title > is generated by selection from databases of automated system;

Lin $\mathrm{O}<$ action > is formed by heuristic activity of technologist;

Line $\mathrm{T}$ <cutting tool > is generated by selection from databases of automated system;
Line $\mathrm{T}$ < accessory> is generated by selection from databases of automated system;

Line $\mathrm{T}$ <measuring tool> is generated by selection from databases of automated system;

Line $\mathrm{R}$ <cutting modes> is formed by computation of cutting modes the main constituents of which are stored in databases of automated system.

The lines of route and process technology are generated from databases of automated system of process development. In intelligent system of process development, each line of route and process technology is presented by individual functional module which contains elementary tables of databases and functional dependences in the form of rules combining these tables into single structure. Operation of intelligent system requires for development of rules and base of precedents, which are functional dependences of adoption of engineering solutions under actual production conditions. The base of precedents stores templates of engineering solutions on processing certain design element and includes the stages of generation of engineering solution.

The stages of formation of technological solution, generated by thinking of technologist nearly automatically on the basis of his experience and knowledge for creation of intelligent system of process development, are multivariant and multilevel task (Fig. 2) with numerous variables both for entry into the system and logout, as well as interaction in the system [5].

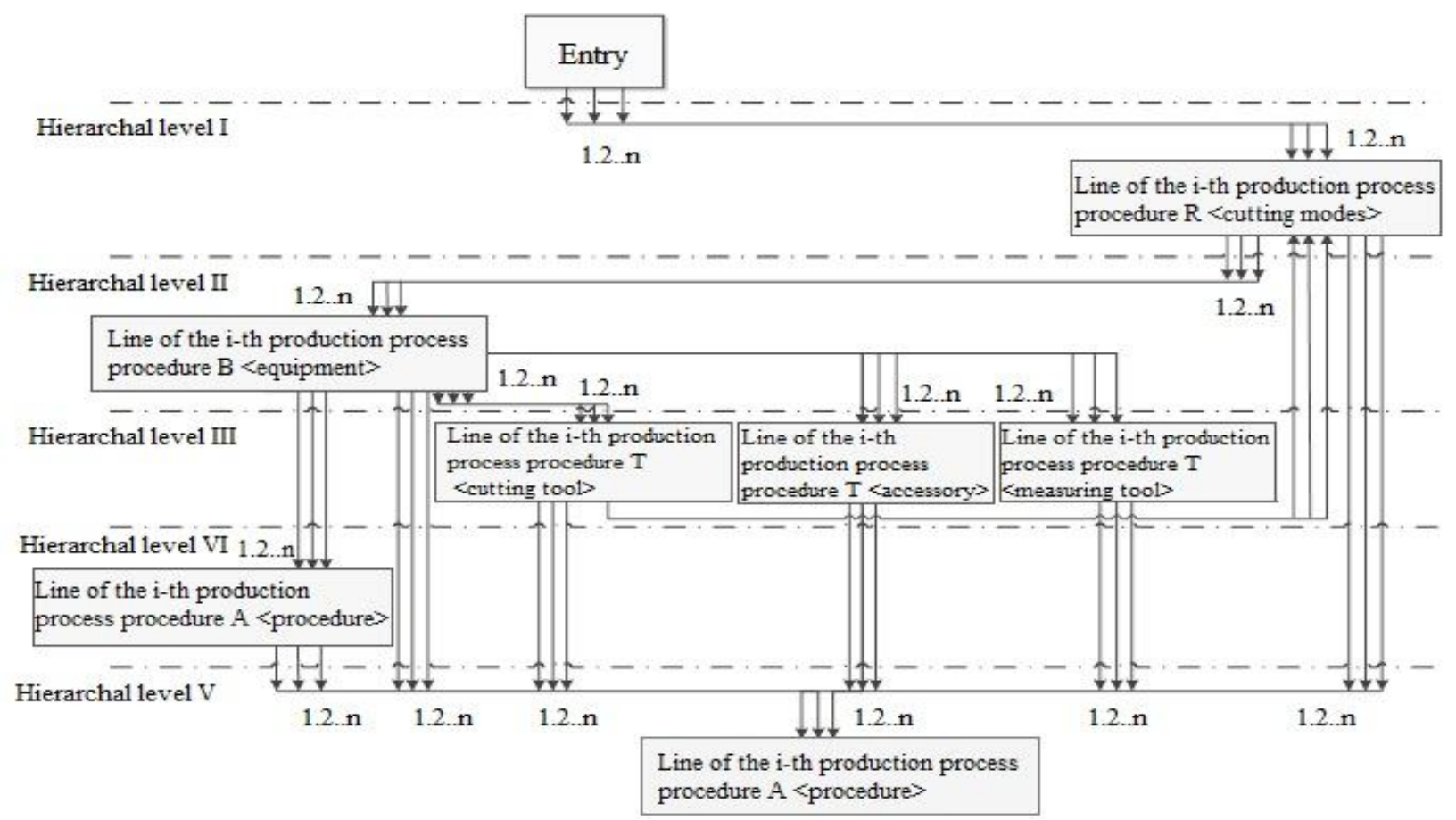

Figure 2: Information flows of clusters of the i-th procedure of production process.

In order to form optimum structure of route and process technology, the matrices (Tables 1,2) of initial data and 
Elena Egorova et al., International Journal of Emerging Trends in Engineering Research, 8(9), September 2020, 6537 - 6540

restrictions of engineering capabilities of production process procedure are developed. The matrix lines reflect hierarchy of levels of production process, and the columns contain information about the properties determining conditions of obtaining required precision of mechanical processing, that is, restrictions to meet these requirements stipulated by material and technical support of production.

Table 1: Matrix of initial data of production process procedure

\begin{tabular}{|c|c|c|c|c|c|c|}
\hline & $\begin{array}{l}\text { Requirements } \\
\text { preset by } \\
\text { drawing (piece) }\end{array}$ & $\begin{array}{l}\text { Characteristic of } \\
\text { production object } \\
\text { (what piece?) }\end{array}$ & $\begin{array}{lr}\text { Conditions } & \text { of } \\
\text { production } & \text { design } \\
\text { elements } & \text { (piece } \\
\text { complexity) } & \\
\end{array}$ & $\begin{array}{l}\text { Properties of } \\
\text { processing } \\
\text { method (how } \\
\text { to process?) }\end{array}$ & $\begin{array}{l}\text { Tools of } \\
\text { processing (how } \\
\text { to process?) }\end{array}$ & $\begin{array}{l}\text { Number of } \\
\text { restrictions (what } \\
\text { will be affected by } \\
\text { the selection?) }\end{array}$ \\
\hline TP & workpiece type & $\begin{array}{l}\text { piece material, } \\
\text { workpiece type }\end{array}$ & & & & $\begin{array}{l}\text { Batch processing } \\
\text { time, electric } \\
\text { power, time of } \\
\text { order fulfillment }\end{array}$ \\
\hline OP & & $\begin{array}{l}\text { output volume, } \\
\text { material hardness }\end{array}$ & number of $\mathrm{DE}$ & $\begin{array}{l}\text { Machine type } \\
\text { (center, } \\
\text { milling, } \\
\text { drilling } \\
\text { machine, etc.) }\end{array}$ & MCS & Processing time \\
\hline UST & & $\begin{array}{lr}\text { number } & \text { of } \\
\text { processed } & \text { piece } \\
\text { sides } & \end{array}$ & piece complexity & $\begin{array}{l}\mathrm{CT} \text { (cutting } \\
\text { tools) }\end{array}$ & fastening tools & $\begin{array}{l}\text { Time pf piece } \\
\text { refastening }\end{array}$ \\
\hline POZ & & & $\begin{array}{l}\text { number of processed } \\
\text { piece sides }\end{array}$ & $\begin{array}{l}\text { equipment } \\
\text { capabilities } \\
(3-, 4-, 5 \text {-axis } \\
\text { machine })\end{array}$ & $\begin{array}{l}\text { additional } \mathrm{CT} \\
\text { tools }\end{array}$ & $\begin{array}{l}\text { Processing time, } \\
\text { set-up time, output } \\
\text { volume }\end{array}$ \\
\hline PER & & & $\begin{array}{l}\text { number of CT in } \\
\text { assembly }\end{array}$ & CT & $\begin{array}{l}\text { CT tools, tool } \\
\text { type }\end{array}$ & Set-up time \\
\hline RKh & & $\begin{array}{l}\text { precision, } \\
\text { roughness }\end{array}$ & CT replacement & $\begin{array}{l}\text { processing } \\
\text { type }\end{array}$ & CT & Processing time \\
\hline
\end{tabular}

Table 2: Matrix of restrictions of production process procedure

\begin{tabular}{|c|c|c|c|c|c|c|}
\hline & \begin{tabular}{l}
\multicolumn{2}{l}{ Requirements } \\
preset by \\
drawing \\
(piece)
\end{tabular} & $\begin{array}{l}\text { Characteristic of } \\
\text { production object } \\
\text { (what piece?) }\end{array}$ & $\begin{array}{lr}\begin{array}{l}\text { Conditions } \\
\text { production }\end{array} & \begin{array}{r}\text { of } \\
\text { design } \\
\text { elements }\end{array} \\
\text { (piece } \\
\text { complexity) }\end{array}$ & $\begin{array}{l}\text { Properties of } \\
\text { processing } \\
\text { method (how } \\
\text { to process?) }\end{array}$ & $\begin{array}{l}\text { Tools of } \\
\text { processing (how } \\
\text { to process?) }\end{array}$ & $\begin{array}{l}\text { Number of } \\
\text { restrictions (what } \\
\text { will be effected by } \\
\text { the selection?) }\end{array}$ \\
\hline TP & workpiece type & $\begin{array}{l}\text { piece material, } \\
\text { workpiece type }\end{array}$ & & & & $\begin{array}{l}\text { Batch processing } \\
\text { time, electric } \\
\text { power, time of } \\
\text { order fulfillment }\end{array}$ \\
\hline OP & & $\begin{array}{l}\text { output volume, } \\
\text { material hardness }\end{array}$ & number of DE & $\begin{array}{l}\text { Machine type } \\
\text { (center, } \\
\text { milling, } \\
\text { drilling } \\
\text { machine, etc.) }\end{array}$ & MCS & Processing time \\
\hline UST & & $\begin{array}{l}\text { number of processed } \\
\text { piece sides }\end{array}$ & piece complexity & CT & fastening tools & $\begin{array}{l}\text { Time pf piece } \\
\text { refastening }\end{array}$ \\
\hline POZ & & & $\begin{array}{l}\text { number of processed } \\
\text { piece sides }\end{array}$ & $\begin{array}{l}\text { equipment } \\
\text { capabilities } \\
(3-, 4-, 5 \text {-axis } \\
\text { machine) } \\
\end{array}$ & $\begin{array}{l}\text { additional } \mathrm{CT} \\
\text { tools }\end{array}$ & $\begin{array}{l}\text { Processing time, } \\
\text { set-up time, output } \\
\text { volume }\end{array}$ \\
\hline PER & & & $\begin{array}{l}\text { number of } \mathrm{CT} \text { in } \\
\text { assembly }\end{array}$ & CT & $\begin{array}{l}\text { CT tools, tool } \\
\text { type }\end{array}$ & Set-up time \\
\hline RKh & & precision, roughness & CT replacement & $\begin{array}{l}\text { processing } \\
\text { type }\end{array}$ & $\mathrm{CT}$ & Processing time \\
\hline
\end{tabular}

In final form, production process is presented as follows: 


$$
P P=\sum_{i=1}^{n} O_{i}
$$

where $\mathrm{O}_{i}$ is the procedure of production process.

The optimum route and procedure technology are formed step by step. At the first step, initial matrix of alternative variants of engineering capabilities of production process procedure is formed. At the second step of planning and preparation of production, the matrix of alternative variants of engineering capabilities of production process procedure is exposed to restrictions by production process. At the third step, optimum structure of route and process technology is selected with consideration for expenses

\section{SUMMARY}

The matrices of initial data and restrictions of engineering capabilities of production process procedure in intelligent system of production process development make it possible to obtain optimum structure of piece processing.

\section{CONCLUSION}

This article has described methodology of formation of matrix of initial data and restrictions of engineering capabilities of production process procedure in intelligent system of production process development. Mechanical processing procedure is decomposed to seven levels, the properties of obtaining required precision are analyzed during mechanical processing with consideration for restrictions by material and technical support of production.

\section{REFERENCES}

1. L. Simonova, Informatsionnoe obespechenie upravleniya tekhnologicheskimi marshrutami. Integrirovannye informatsionnye sistemy v mashinostroenii [Information support of management of process routes. Integrated information system in engineering industry]. Saarbrücken: LAP LAMBERT Academic Publishing,2012.

2. V.G. Shibakov, Intellektual'naya sistema formirovaniya tekhnologicheskikh protsessov shtampovochnogo proizvodstva na osnove CALS-tekhnologii [Intelligent system of development of production processes in metal forming industry using CALS technologiy]. Kama State Academy of Engineering and Economics. Moscow: Academia, 2011.

3. L.A. Simonova, E.I. Egorova, Modular representation of the product in the knowledge base in the technological process formation. International Scientific Conference, 2015.

4. L.A. Simonova, E.I. Egorova, Development of structural element precedent of technological process in computer-aided design. International Scientific Conference, 2015.

5. L. Simonova, E. Egorova, A. Akhmadiev, Knowledge Acquisition for Engineering Decisions Based on Functional Relationships, International Journal of
Emerging Trends in Engineering Research, vol. 8, no. 6, pp. 2774-2778, 2020.

6. E.I. Egorova, L.A. Simonova, Ontologicheskaya model' predstavleniya informatsii o tekhnologicheskom protsesse detali [Ontological model of information presentation about production process of piece]. Nauchno-tekhnicheskii vestnik Povolzh'ya, no. 11, pp. 247-255, 2018.

7. L.A. Simonova, E.I. Egorova, A.I. Akhmadiev, Modul' formirovaniya marshrutov obrabotki poverkhnostei na osnove nechetkoi logiki [Module of surface processing routes on the basis of fuzzy logics]. Nauchno-tekhnicheskii vestnik Povolzh'ya, no. 11, pp. 81-87, 2019.

8. E.I. Egorova, Representation of Information about Part on The Basis of Its Engineering Features, International Journal of Innovative Technology and Exploring Engineering, vol. 8, no. 12, 2019.

9. E.I. Egorova, V.N. Matveev, Intellektual'naya sistema postroeniya tekhnologicheskikh protsessov po konstruktivno-tekhnologicheskim kharakteristikam detali [Intelligent system of development of production processes by specifications of piece]. Kuznechno-shtampovochnoe proizvodstvo. Obrabotka materialov davleniem, no. 11, pp. 33-40, 2012. 